\title{
Maduro vs Guaidó: nork dauka Venezuela gobernatzeko konstituzio-zilegitasuna?
}

\author{
Eneko Compains Silva \\ Konstituzio Zuzenbideko irakaslea UPV/EHUn
}

\begin{abstract}
Iragan urtarrilaren 23an, oposizioaren manifestaldi baten amaieran, Juan Guaidók Venezuela eta mundua bera harritu zuen bere burua herrialdeko lehendakari arduradun izendatuz. Bere hitzetan, urrats hori Konstituzioaren artikuluen babesean eman zuen, zeinek hautaturiko presidenterik ezean aukera emango luketen Asanblada Nazionaleko presidentea herrialdeko lehendakari arduradun izendatzeko. Eztabaida politikoaz harago, erabakiak eztabaida juridikoa piztu zuen eta hain zuzen ere hori bera da artikulu honen bidez aztertu nahi dena. Nork dauka Venezuela gobernatzeko konstituzio-zilegitasuna?
\end{abstract}

GAKO-HITZAK: Venezuela · Konstituzio-zilegitasuna · Hauteskundeak · Estatukolpea - Demokrazia.

\section{Maduro vs Guaidó: Who has constitutional legitimacy to govern Venezuela?}

On January 23, at the end of an opposition demonstration, Juan Guaidó surprised Venezuela and the entire world by proclaiming himself President in charge of the Bolivarian Republic of Venezuela. In his own words, he made the decision based on the articles of the Venezuelan Constitution, articles that would allow, in the absence of a validly elected President, to «entrust» the Presidency of the Republic to the President of the National Assembly. The decision, beyond the political debate, generated a great legal debate that is analyzed through this essay. Who has constitutional legitimacy to govern Venezuela, Maduro or Guaidó? This is the main question we will try to answer.

KEY WORDS: Venezuela · Constitutional legitimacy · Elections · Coup d'état · Democracy. 


\section{Sarrera ${ }^{1}$}

Gauza jakina da Venezuelak, urte batzuetatik hona, krisialdi politiko, ekonomiko eta sozial sakona bizi duela, herrialdearentzako zorigaiztoko ondorioak izaten ari dena. Lan honen xedea, ordea, ez da aipatu krisialdiaren jatorri eta arrazoien gainean eztabaidatzea izango, Konstituzio Zuzenbidearen ikuspegitik haren azken adierazpenetako baten azterketa egitea baizik.

Joan zen 2019ko urtarrilaren 23an², oposizioaren mobilizazio bat amaitzean, Juan Guaidó Asanblada Nazionaleko presidenteak Venezuelako konstituzio-historian aurrekaririk ez zuen iragarpena egin zuen, bere burua herrialdeko lehendakari aldarrikatuz ${ }^{3}$. Bere adierazpenean Konstituzioari aipamena egin bazion ere, esan beharra dago protokolo eta prozedura-arau guztiak alboratuz eman zuela urratsa (kale erdian, manifestaldi baten amaieran, agertoki batera igota eta Estatuko agintari politiko, judizial eta elektoralak bertan egon gabe) ${ }^{4}$.

Egiari zor, oposizioak, egunak zeramatzan bere asmoez ohartarazten. Urtarrilaren 15ean, esaterako (Nicolás Madurok Errepublikako presidente-kargua zin egin eta bost egunera), 2018ko presidentetzarako hauteskundeen emaitzak onartzen ez zituela adierazten zuen akordioa onartu zuen Asanblada Nazionalean, horrekin batera Maduro presidentetza usurpatzen ari zela adieraziz (Asamblea Nacional de Venezuela, 2019a). Akordioan, gainera, usurpazio-egoera guztiz ezezaguna zela adierazten zen; herrialdeko historia hurbilean aurrekaririk gabekoa zela eta «Konstituzioan esanbidezko irtenbiderik» ez zuela. Ez zegoen, haien esanetan, legearen arabera hautatutako lehendakaririk ez eta hori konpontzeko konponbide espresik ere Konstituzioan. Zer egin, orduan, ustezko hutsune juridiko-konstituzional horren aurrean? Zein izan zen oposizioak Asanblada Nazionalean adostutako irtenbidea?

Bada, funtsean, hiru gauza egin zituen. Baga: Asanblada Nazionala «Estatuko autoritate zilegi bakar eta Venezuelako herriaren ordezkari» izendatu. Biga: de facto, konstituzio-testuaren interprete goren bezala jokatu (Konstituzioaren 335. artikuluan

1. Lan hau Euskal Unibertsitate Sistemako «Oinarrizko Eskubideak eta Europar Batasuna» ikerketatalde kontsolidatuaren babesean egina da. Egileak, era berean, Eguzkiñe Aiesa Udalbiltza Partzuergoko idazkariak euskara juridikoarekin emandako laguntza aitortu nahi du.

2. Oso data sinbolikoa da Venezuelan, azken diktadura militarraren uzkailtzearen urteurrena ospatzen baita. Zehazki, Marcos Pérez jeneralak zuzentzen zuen, militar eta herritarren altxamendu batek 1958ko urtarrilaren 23an uzkaili zuen arte. Gertakari hark lau hamarkadako demokrazia formal bati eman zion bide (herritarren artean Puntofijismo izenez ezagutzen den garai historikoa, 1998an Chávez boterera heltzean amaitu zena) (Bonilla-Molina eta El Troudi, 2005: 34 eta hur.; Compains, 2016: 136 eta hur.).

3. «Última hora! Juan Guaidó se proclama Presidente encargado de Venezuela», Youtube, 2019/01/23 (azken kontsulta: 2019/05/13). Ikus: <https://www.youtube.com/watch?v=1xSRWhlklxo>.

4. Gabezia hori nabarmendu zuen lehen unetik Konstituzio Zuzenbideko irakasle eta Konstituzio Auzitegiaren letradu ohi den Joaquín Uríasek: «Teknikoki honakoa da zehazki. Manifestazio batean zehar bere burua bere herrialdeko presidente izendatu duen gizon bat. Legearen nagusitasuna defendatzen dutenak koherente izan eta legez kanpoko iruzur hau estatu-kolpea baino ez dela onar dezatela espero dut. Maduro gogoko izan gabe ere». Ikus: <https://twitter.com/jpurias/status/1088146090157920257> (azken kontsulta: 2019/05/13). 
ezarritakoa nabarmen urratuz) $)^{5}$. Higa: «Konstituzioaren 5., 187., 233., 333. eta 350. artikuluen babesaz konstituzio-ordenaren indarraldia berrezartzeko erabakiak» hartuko zituela iragarri.

Gure ustez, bereziki garrantzitsua da Konstituzioaren 233. artikulua analogikoki aplikatzeari ekitea onartu izana, artikulu horrek, baldintza jakin batzuetan, Errepublikako lehendakaritza Asanblada Nazionaleko presidentearen «ardurapean jartzea ${ }^{6} »$ baimentzen baitu. Eta noski, horixe bera baliatu zuen Guaidók bere burua lehendakari aldarrikatzeko.

Berez, ez dirudi arau konstituzional baten aplikazio analogikoa oinarririk sendoena denik lehendakari bat izendatzeko, are gutxiago XXI. mendean. Alabaina, berehalakoan eta nazioarteko harremanetan eraendu ohi den zuhurtasun-printzipioa alde batera utzita, AEBko presidente Donald Trumpek, Twitter bidez, Juan Guaidó Venezuelako «bitarteko ${ }^{7}$ » lehendakari aintzatetsi zuen, eta ordu gutxiren buruan Limako Taldeak ${ }^{8}$ eta Europar Batasuneko hainbat estatuk haren urratsei jarraituko zieten.

Horren aurrean, zilegi dirudi galdetzea non geratzen diren Nazioarteko Zuzenbide Publikoarekiko errespetua, herrien autodeterminazioarekikoa, estatuen arteko berdintasun subiranoarekikoa edota beste herrialde baten barne-arazoetan ez sartzeko printzipioarekikoa. Izan ere, NBEren posizioari erreparatzen badiogu, askoz ere posizio zuhurragoa eta Nazioarteko Zuzenbideari lotutakoa dela ikus dezakegu. Horrela, Nicolás Maduro Errepublikako lehendakari legitimotzat hartu eta bere organo guztietan bai haren kantzilerra nola gainerako ordezkariak onartzen jarraitzen duela ikus dezakegu .

5. 335. art.: «El Tribunal Supremo de Justicia garantizará la supremacía y efectividad de las normas y principios constitucionales; será el máximo y último intérprete de esta Constitución y velará por su uniforme interpretación y aplicación. Las interpretaciones que establezca la Sala Constitucional sobre el contenido o alcance de las normas y principios constitucionales son vinculantes para las otras Salas del Tribunal Supremo de Justicia y demás tribunales de la República».

Venezuelako aditurik entzutetsuenetako bat den Allan Brewer-Carías gertakari hau justifikatzen saiatu da azken aldian, horretarako Parlamentua Konstituzioaren lehen interprete dela baieztatuz. Horretarako, Pérez Royo konstituzionalista ezagunaren hitzak baliatzen baditu ere, Venezuelako Konstituzioa oso argia da. JAG da Konstituzioaren interprete gorena, eta zehazkiago, bere Konstituzio Aretoa (BrewerCarías, 2019a: 13 eta hur.; Pérez Royo, 2005: 889).

6. Argibidea: ardura ematea eta onartzea ez dira gauza bera. Presidenteak kargua «onartzen» duenean, beronen eskumen guztiekin egiten du. Aldiz, Errepublikako presidentetzaren «ardura» ematen denean, presidente «arduradunak» hauteskunde berriak egin eta presidente berria hautatu arteko administrazio-egintzak baino egin ezin ditzakeela esan nahi du.

7. Venezuelako Konstituzioan existitzen ez den figura juridikoa «bitarteko» presidentearena.

8. Limako Taldea 2017ko abuztuaren 8an hiri horretan Latinoamerikako 14 herrialdeetako ordezkariak Venezuelako krisialdiari jarraipena egin eta irtenbidea bilatzeko bildu eta Limako Adierazpena deiturikoa izenpetu eta gero ezarritako instantzia aldeaniztuna da. Politikoki, AEBren eta Donald Trump presidentearen aginduei jarraitzen diete.

9. «Naciones Unidas reconoce a Maduro como Presidente de Venezuela», Radio Rebelde, 2019ko otsailaren 1a. Ikus: <http://www.radiorebelde.cu/comentarios/naciones-unidas-reconoce-maduro-comopresidente-venezuela-20190201/> (azken kontsulta: 2019/05/13). 
Baina utz ditzagun Nazioarteko Zuzenbideko auziak alde batera. Gaur arte, gertaerek herrialdeko lehendakaria Nicolás Maduro ${ }^{10}$ dela erakusten dute. Bera da errealitatean Gobernuaren ekintza zuzentzen duena, ministroak izendatzen dituena, Guardia Nazional Bolibartarra zuzentzen duena, mugen itxiera agintzen duena... finean, Konstituzioaren 236. artikuluak Errepublikako lehendakariari egozten dizkion funtzio guztiak praktikan egikaritzen dituena ${ }^{11}$. De facto, beraz, gauzak argi daude. Baina de iure? Nork dauka Venezuela gobernatzeko konstituzio-zilegitasuna? Ba al dute oposizioak eta Juan Guaidók egin zutena egiteko zuzenbide-zilegitasunik? Estatu-kolpe saiakera zatar baten aurrean gaude ala, batzuek baieztatzen duten bezala, Venezuelak lehendakari berria du?

\section{Zer dio Venezuelako Konstituzioak?}

Venezuelako 1999ko Konstituzioak, Latinoamerikako herrialde gehienetakoak bezala, gobernu-sistema presidentzialista bat ezartzen du. Alegia, herrialdeko eskema instituzionalean Errepublikako lehendakaria lehentasunezko posizioan jarri eta botere legegilearen eta betearazlearen arteko bereizketa zorrotza ezartzen du. Eta zer esan nahi dugu «bereizketa zorrotzaz» ari garenean? Bada, batetik, lehendakariak gobernatu ahal izateko Parlamentuaren konfiantzaren beharrik ez duela, ez baita azken hori hura izendatzen duena. Bestetik, Parlamentuak ez duela lehendakaria kargugabetzeko eskumenik, bere aurkako zentsura-moziorik edo antzekorik ez baita aurreikusten Konstituzioan ${ }^{12}$.

Zehazki, 1999ko Konstituzioak jasotzen duenez, Errepublikako lehendakaria estatuburua da eta Gobernuaren ekimena zuzentzen du (226. artikulua). Herriak soilik «jar edo ken» dezake lehendakaria. Jarri: bozketa unibertsal, zuzen eta sekretu bidez hautatuz (228. art.); edo kendu: baliogabetze-erreferendum bidez bere agintaldi presidentzialetik botaz (72. art.).

Horretaz gain, lehendakaritza-agintea sei urtekoa da (230. art.) eta lehendakariak bere konstituzio-aldiaren lehenengo urteko urtarrilaren 10a baino lehenago zin egin behar du kargua, hautatutako lehendakari izatetik lehendakari izatera pasatzeko.

10. Emir Saderrek nahiko argi azaltzen du honako artikuluan: Sader, Emir (2019): «Venezuela tiene un solo Presidente», Diario Público, 2019ko otsailaren 27a. Ikus: <https://blogs.publico.es/emirsader/2019/02/27/venezuela-tiene-un-solo-presidente/> (azken kontsulta: 2019/05/13).

11. 236. art.: "Son atribuciones y obligaciones del Presidente o Presidenta de la República: 1. Cumplir y hacer cumplir esta Constitución y la ley. 2. Dirigir la acción del Gobierno. 3. Nombrar y remover al Vicepresidente Ejecutivo o Vicepresidenta Ejecutiva; nombrar y remover los Ministros o Ministras. 4. Dirigir las relaciones exteriores de la República y celebrar y ratificar los tratados, convenios o acuerdos internacionales. 5. Dirigir la Fuerza Armada Nacional en su carácter de Comandante en Jefe, ejercer la suprema autoridad jerárquica de ella y fijar su contingente. 6 . Ejercer el mando supremo de la Fuerza Armada Nacional, promover sus oficiales a partir del grado de coronel o coronela o capitán o capitana de navío, y nombrarlos o nombrarlas para los cargos que les son privativos. 7. Declarar los estados de excepción y decretar la restricción de garantías en los casos previstos en esta Constitución. 8. Dictar, previa autorización por una ley habilitante, decretos con fuerza de ley. 9. Convocar la Asamblea Nacional a sesiones extraordinarias. 10. Reglamentar total o parcialmente las leyes, sin alterar su espíritu, propósito y razón. 11. Administrar la Hacienda Pública Nacional...».

12. Lehendakariordearen aurka, ordea, aurkez daiteke. Asanblada Nazionalaren funtzioak ezartzen dituen Konstituzioaren 187.10 artikuluan jasota dago.

UZTARO 112, 87-105 90

Bilbo, 2020ko urtarrila-martxoa 
Printzipioz, Asanblada Nazionalaren aurrean egin behar du, baina bat-bateko arrazoiren bat dela medio hori posible ez balitz, Justizia Auzitegi Gorenaren (aurrerantzean JAG) aurrean egin dezake (231. art).

Konstituzioak Asanblada Nazionaleko presidenteari Errepublikako lehendakaritzaren ardura ematea aurreikusten duen kasu bakarra 233. artikuluan ${ }^{13}$ arautzen dena da, hautatutako lehendakariaren huts absoluturik ematen baldin bada (izan heriotza, uko egitea, ezintasun fisiko edo mentala...) karguaren zin-egite ekitaldia baino lehenago.

Artikulu hori, beraz, Juan Guaidóren autoizendapenaren inguruko eraikuntza juridikoa ulertzeko guztiz funtsezkoa da; baina arestian esan bezala, horrekin batera, Asanblada Nazionalak, 333. eta 350. artikuluak ere aipatu zituen, besteak beste, garrantzi txikiagoko beste batzuen artean.

Bi horietako lehenak Konstituzioaren VIII. Titulua irekitzen du (Konstituzioaren Zainketa arautzen duena) eta «autoritatea duen nahiz ez duen» edozein herritar Konstituzioaren indarraldia berrezartzen laguntzera behartzen $\mathrm{du}^{14}$. Bigarrena ${ }^{15}$, berriz, Konstituzioaren itxiera-artikulua da eta ius resistendi (Biagini, 1978: 153-160) delakoaren konstituzionalizazioa ezartzen du. Horrek esan nahi al du Venezuelan desobedientziarik absolutuenari konstituzionalki ateak zabaltzen zaizkiola? Parlamentuak, esaterako, epailetza desobeditu dezakeela? Inolaz ere ez. JAGk 2002an oso argi utzi zuen honako xedapena lan konstituziogilearen emaitzaren ondorio dela, zeinak Venezuelako herria lan horretan aurreikusitako eskubide naturalen printzipioak urratzen dituen edozein arau ez onartzera baimentzen duen. Alabaina, Tribunalaren aburuz, guztiz lekuz kanpo dago artikulu hori

13. 233. art.: «Serán faltas absolutas del Presidente o Presidenta de la República: su muerte, su renuncia, o su destitución decretada por sentencia del Tribunal Supremo de Justicia; su incapacidad física o mental permanente certificada por una junta médica designada por el Tribunal Supremo de Justicia y con aprobación de la Asamblea Nacional; el abandono del cargo, declarado como tal por la Asamblea Nacional, así como la revocación popular de su mandato. Cuando se produzca la falta absoluta del Presidente electo o Presidenta electa antes de tomar posesión, se procederá a una nueva elección universal, directa y secreta dentro de los treinta días consecutivos siguientes. Mientras se elige y toma posesión el nuevo Presidente o la nueva Presidenta, se encargará de la Presidencia de la República el Presidente o Presidenta de la Asamblea Nacional. Si la falta absoluta del Presidente o la Presidenta de la República se produce durante los primeros cuatro años del período constitucional, se procederá a una nueva elección universal, directa y secreta dentro de los treinta días consecutivos siguientes. Mientras se elige y toma posesión el nuevo Presidente o la nueva Presidenta, se encargará de la Presidencia de la República el Vicepresidente Ejecutivo o la Vicepresidenta Ejecutiva. En los casos anteriores, el nuevo Presidente o Presidenta completará el período constitucional correspondiente. Si la falta absoluta se produce durante los últimos dos años del período constitucional, el Vicepresidente Ejecutivo o la Vicepresidenta Ejecutiva asumirá la Presidencia de la República hasta completar dicho período».

14. 333. art.: «Esta Constitución no perderá su vigencia si dejare de observarse por acto de fuerza o porque fuere derogada por cualquier otro medio distinto al previsto en ella. En tal eventualidad, todo ciudadano investido o ciudadana investida o no de autoridad, tendrá el deber de colaborar en el restablecimiento de su efectiva vigencia».

15. 350. art.: «El pueblo de Venezuela, fiel a su tradición republicana, a su lucha por la independencia, la paz y la libertad, desconocerá cualquier régimen, legislación o autoridad que contraríe los valores, principios y garantías democráticos o menoscabe los derechos humanos». 
aipatzea Estatuko organo batek egindako Konstituzioaren berariazko urraketa bat justifikatzeko (Asanblada Nazionalaren kasuan bezala) ${ }^{16}$.

Guztiarekin, eta bi artikulu horiek arrazoibide juridikoa osatzeko garrantzi handiagoa edo txikiagoa izan, Asanblada Nazionalak berak zio juridiko nagusia 233. artikuluaren interpretazioa eta aplikazioa zirela onartu zuen, eta ondorioz, horren azterketan jarriko ditugu gure indarrak.

\section{Konstituzioaren 233. artikulua aplikagarri al da aztertzen ari garen kasuan?}

Asanblada Nazionalean oposizioak berak adostutakoari jaramon eginez gero, erantzuna argia da: ez. Funtsean, artikulu horren aplikaziorako baldintza delako hautatutako lehendakari bat existitzea, aztertzen ari garen kasuan oposizioak ukatzen duen zerbait.

Esan bezala, oposizioak, 2018ko maiatzaren 20an hauteskunde-prozesu baliodunik egon izana ukatu zuen eta, ondorioz, 2019ko urtarrilaren 10etik aurrera kargua usurpatzen ariko litzateke Maduro. Horren aurrean zera esan daiteke: horrela balitz (eta ez dugu uste hala denik), 2019-2025 agintaldirako boterehutsunea legoke, bai, baina aitzitik, ez luke inplikatuko 233. artikuluak arautzen duen hautatutako lehendakariaren falta absoluturik. Horrela nabarmendu dute baita egungo lehendakariaren aurkako zenbait adituk ere ${ }^{17}$.

Behin aurrekoa esanda, egin dezagun ariketa bat: Demagun AEBko lehendakari ohia den Jimmy Carterrek 2012an Venezuelako hauteskunde-sistema «munduko onena ${ }^{18}$ » dela baieztatu zuenean ez zuela gezurrik esan (bozka digitala eta paperekoa izatean eskaintzen duen berme bikoitza dela-eta). Jar dezagun, ondorioz, 2018ko

16. «[...] Aparte de la hipótesis antes descrita sólo debe admitirse en el contexto de una interpretación constitucionalizada de la norma objeto de la presente decisión, la posibilidad de desconocimiento o desobediencia, cuando agotados todos los recursos y medios judiciales, previstos en el ordenamiento jurídico para justiciar un agravio determinado, producido por "cualquier régimen, legislación o autoridad", no sea materialmente posible ejecutar el contenido de una decisión favorable. En estos casos quienes se opongan deliberada y conscientemente a una orden emitida en su contra e impidan en el ámbito de lo fáctico la materialización de la misma, por encima incluso de la propia autoridad judicial que produjo el pronunciamiento favorable, se arriesga a que en su contra se activen los mecanismos de desobediencia, la cual deberá ser tenida como legítima sí y solo sí -como se ha indicado precedentemente- se han agotado previamente los mecanismos e instancias que la propia Constitución contiene como garantes del estado de derecho en el orden interno, y a pesar de la declaración de inconstitucionalidad el agravio se mantiene [...]". Venezuelako JAGren Konstituzio Aretoaren 24. epaia, 2003ko urtarrilaren 22koa.

17. «El problema en Venezuela no es la falta absoluta de quien fuera electo como presidente, sino la inexistencia de una persona que ha sido válidamente electa como presidente, pues el 20 de mayo no ha sido reconocido como una elección libre y transparente. Esto quiere decir que el supuesto de hecho del artículo 233 de la Constitución es distinto a los hechos actuales. Con lo cual, y al contrario de lo que parece creerse, el artículo 233 de la Constitución no es la norma aplicable a la crisis actual» (Hernández, 2019a).

18. «Jimmy Carter: el sistema electoral venezolano es el mejor del mundo», Russia Today, 2012ko irailaren 20a Ikus: <https://actualidad.rt.com/actualidad/view/54145-jimmy-carter-sistema-electoralvenezolano-mejor-mundo> (azken kontsulta: 2019/05/13). 
maiatzaren 20an lehendakaritzarako hauteskundeak egin, egin zirela. Demagun, era berean, Hauteskunde Kontseilu Nazionalak (aurrerantzean HKN) -2015eko legegintza-hauteskundeetan oposizioari garaipena eman zion organo berak- egun hartarako hauteskunde-prozesu demokratiko, libre eta gardena bultzatu zuela, zeinean hala nahi izan zuten oposizioko hautagaiek parte hartzeko aukera librea izan zuten. Demagun, ere bai, Nicolás Maduroren garaipena aldarrikatzean egia esan zuela $\mathrm{HKNk}^{19}$. Demagun, gainera, hauteskunde haietan oposizioko hainbat hautagaik parte hartu zutela milioika boz jasoz, Bertucci edo Falcón kasu (azken hori COPElk, Espainiako Alderdi Popularraren «anaiak», babestutako hautagaia). Erantsi dezagun, amaitzeko, lehendakaritzarako hauteskunde haiek aurrez, egunean bertan eta ondoren jarraitu zituzten nazioarteko begiraleek prozesua garbia eta demokratikoa izan zela baieztatzean gezurrik esan ez zutela ${ }^{20}$.

Kasu horretan, modu baliagarrian hautatutako lehendakaria legokeenez, posible al litzateke Juan Guaidó herritarrari lehendakaritzaren ardura emateko 233. artikulua aplikatzea? Bada ez, denbora horretan aipatu artikuluak lehendakariaren huts absolutua emateko ezartzen dituen sei arrazoietatik bakarra ere eman ez delako: heriotza, uko egitea, JAGk kargugabetzea, ezgaitasun fisiko edota mental iraunkorra, Asanblada Nazionalak ebatzitako karguaren abandonua eta herriak erreferendum bidez agintaldia baliogabetzea.

Arrazoi horietatik guztietatik, Asanblada Nazionalak ebatzitako karguaren abandonuarena da eztabaida juridiko minimoa sor dezakeen bakarra, gainerakoak ematen ez direla begi-bistakoa baita. Nicolás Madurok kargua abandonatu izana, ordea, 2017an ebatzi zuen Asanblada Nazionalak modu solemnean, eta horrek bere azterketa merezi du. Zer gertatu zen zehazki?

2017ko urtarrilaren 9an Asanblada Nazionalak Nicolás Maduro lehendakaria karguaren abandonuan deklaratu zuen (Asamblea Nacional de Venezuela, 2017), aipatutako adierazpenak ibilbide handirik izan ez bazuen ere, helegitea aurkeztu eta auzitegi eskudunek zuzenbide osoz deuseztatu baitzuten. Eztabaida juridiko sakona eman zen ordea, ordura arte karguaren abandonua esamolde juridikoaren esanahiaren inguruan argitasunik ez zegoelako, ez eta zein premisatan oinarrituz ebatz zitekeen ere.

Brewer-Caríasek gogorarazten duen bezala, karguaren abandonua lehendakariaren huts absolutuaren suposizioen artean Asanblada Nazionalak, beste inoren beharrik gabe, dekretatu dezakeen bakarra da (Brewer-Carías, 2018: 491-511). Horretan ez dago zalantzarik. Funtsean, afera korapilatu egiten da Konstituzioak ez baitu zehazten Asanblada Nazionalak aipatu abandonua zein kasutan ebatz dezakeen, kasu bakarra zehaztuz: falta tenporal bat falta absolutu bilakatzea (234.

19. Emaitza ofizialak HKNren web orrian kontsulta daitezke. Ikus: <http://www.cne.gob.ve/ ResultadosElecciones2018/> (azken kontsulta: 2019/05/13).

20. «Los observadores internacionales avalan la reelección de Maduro», eitb.eus, 2018ko maiatzaren 22a. Ikus: <https://www.eitb.eus/es/noticias/internacional/detalle/5608975/venezuela-elecciones-losobservadores-avalan-reeleccion-maduro/>. 
art. ${ }^{21}$ ). Hau da, Konstituzioaren arabera, karguaren abandonua aldi baterako falta, falta absolutu bilakatzean emango litzateke.

Hala eta guztiz ere, jurista horren arabera, aurrekoak ez luke aipatu abandonua ematen ahalko litzatekeen kasuen zerrenda agortuko. Beste aukera bat, betiere jurista aipagarri horren aburuz, karguaren abandonua lehendakariaren erantzukizun politikoaren adierazpenetik eratorria izatea izan liteke, «bere funtzioen abandonuan erori dela baloratzen den kasuetan (222 art. ${ }^{22}$ ), hau da, bere konstituzio-betebeharrak bete gabe utzi dituenean ${ }^{23}$ ».

Hori da, hain zuzen, Asanblada Nazionalak bere 2017ko urtarrilaren 9ko akordioa hartzeko jarraitutako tesia, Maduro, hainbat arrazoi zirela-eta, karguaren abandonuegoeran zegoela baieztatu zuelarik. Zeintzuk izan ziren, zehazki, aipatu arrazoiak? Bada, Konstituzioaren 2., 7. eta 236.1 artikuluak ez errespetatu izana (hurrenez hurren zuzenbide- eta justizia-estatu demokratikoa, Konstituzioaren nagusitasuna eta legeak bete eta betearaztearen betebeharra ezartzen dutenak); kudeaketa ekonomiko eta finantzario txarra egin izana; herritarren segurtasuna bermatzeko ezgaitasuna erakutsi izana, etab.

Baina, esan den bezala, Asanbladaren ebazpena auzitegien aurrean aurkaratua izan zen (deuseztasun-helegite baten bidez) eta, 335. artikuluaren aginduz, Konstituzioaren interprete gorena den JAGren Konstituzio Aretoak oso bestelako erabakia hartu zuen.

Auzitegiak, esan beharra dago, deuseztasun-helegite hura konstituzio-kontrakoa izateagatik errefusatu zuen, baina ez motibazio faltagatik, res licata izateagatik baizik, egun batzuk lehenago, Asanblada Nazionalak bere hainbat sententziari desmen egiteagatik legegintza ez-egite egoeran deklaratu baitzuen, Asanbladak emandako egintza guztien deuseztasuna adieraziz (legeak barne) (Asamblea Nacional de Venezuela, 2017). Hori bai, jarraian, karguaren abandonuak eragindako falta absolutuaren esanahia argitzeak zuen garrantzia juridikoa ikusita, zioa behin betiko argitzen zuen obiter dictum bat eman zuen.

Laburbilduz, auzitegiak honakoa baieztatu zuen: karguaren abandonuak beti eragiten du kargu horrekiko bereizte fisiko borondatezko eta arbitrario bat, eta inolaz ere balizko efizientzia eza funtzioen betetzean. Beraz, karguaren abandonuak hiru

21. 234. art.: «Las faltas temporales del Presidente o Presidenta de la República serán suplidas por el Vicepresidente Ejecutivo o Vicepresidenta Ejecutiva hasta por noventa días, prorrogables por decisión de la Asamblea Nacional hasta por noventa días más. Si una falta temporal se prolonga por más de noventa días consecutivos, la Asamblea Nacional decidirá por mayoría de sus integrantes si debe considerarse que hay falta absoluta».

22. 222. art.: «La Asamblea Nacional podrá ejercer su función de control mediante los siguientes mecanismos: las interpelaciones, las investigaciones, las preguntas, las autorizaciones y las aprobaciones parlamentarias previstas en esta Constitución y en la ley, y mediante cualquier otro mecanismo que establezcan las leyes y su reglamento. En ejercicio del control parlamentario, podrán declarar la responsabilidad política de los funcionarios públicos o funcionarias públicas y solicitar al Poder Ciudadano que intente las acciones a que haya lugar para hacer efectiva tal responsabilidad».

23. Idem.

UZTARO 112, 87-105 
ezaugarri bereizgarri lituzke: 1) kargua uzteko borondatea; 2) justifikazio eza; eta 3) ausentzia hori iraunkorra edo definitiboa izatea ${ }^{24}$.

Ondorioz, Aretoak halako karguaren abandonurik ez zegoela eta onartutakoa oposizioak Asanblada Nazionalean egindako maniobra baino ez zela ezarri zuen, «Nazioaren ordena politiko eta soziala gainazpikatzen zuen mekanismo argiki konstituzio-kontrakoaren bidez» Errepublikako presidenteari epaiketa politikoa egitea asmo zuena, «ondoz ondoko kargugabetze-efektuak izanik», horretarako konstituzio-eskumenik ez bazuen ere.

Puntu honetan, Venezuelako gobernu-sistema presidentzialista dela gogora ekartzea komeni da. Aretoak, Brewer-Carías bera aipatuz gogorarazi zuen bezala, sistema presidentzialistetan «Gobernuaren ekintza lehendakariari dagokio, herriak hautatua dena eta jarduterako Asanblada Nazionalaren konfiantzazko botoaren mende ez dagoena». Sistema parlamentarioetan gertatzen denaren kontrakoa gertatzen da sistema presidentzialetan; lehenengoetan «Gobernuaren hautaketa Parlamentuaren esku dago eta politikoki horren aurrean erantzule da».

Zer dakar aurrekoak? Bada, aurretik esan den bezala, Venezuelako sistema politiko eta konstituzionalean Parlamentuak ez duela lehendakaria kargugabetzeko mekanismorik eta, ondorioz, oposizioak ezin duela Konstituzioaren iruzurreko interpretaziorik baliatu karguaren abandonuaren deklarazio bidez epaiketa politikoa egiteko; de facto, zentsura-moziorik gauzatzeko.

Aztertzen ari garen kasurako, ondorio nagusia da ustezko «karguaren abandonuak» ez ziola Juan Guaidóri lehendakari autoizendatzeko eskumenik emango. Lehenik, aipatu karguaren abandonurik eman ez delako; ez, bederen, JAGren Konstituzio Aretoak lotesletzat dituen terminoetan. Eta bigarrenik, hori deklaratzen zuen akordioa zuzenbide osoz deuseza delako.

Baina, akordioa juridikoki balioduna izan balitz eta Madurok kargua abandonatu izan balu? Konstituzionalki zilegi al litzateke, orduan, Juan Guaidó lehendakari autoizendatzea? Hirugarrenez: ez. Kasu horretan lehendakaritzaren ardura Errepublikako egungo lehendakariordeari eman beharko zitzaiokeen; alegia, Delcy Rodríguezi.

Konstituzioaren 233. artikulua nahiko argia da horri dagokionez. Bere esanahi literaletik ondoriozta daitekeenez, artikulu horren aplikazio-uneak hiru dira, haietako bakoitzak ondorio juridiko ezberdina duelarik:

- Lehen unea: falta absolutua lehendakariaren aldarrikatzearen eta zin egitearen artean gertatzen bada, lehendakaritzaren ardura Asanblada Nazionalaren presidenteari ematen zaio, zeinak hilabeteko epean hauteskundeak deitzeko betebeharra baitu.

24. "Siempre el abandono del cargo (del trabajo o de funciones) implica una separación física, voluntaria y arbitraria del trabajador (o funcionario público) y no una "presunta" ineficiencia en el desempeño de sus funciones, de lo cual se derivan tres elementos distintivos del mismo, cuales son la voluntad de dejar el cargo, que no haya motivo o justificación, y que esa ausencia sea permanente y definitiva». Venezuelako JAGko Konstituzio Aretoaren 7. epaia, 2017ko urtarrilaren 26koa. 
- Bigarren unea: falta absolutua lehendakariaren zin egitearen ondoren eta agintaldiaren lehenbiziko lau urteen barruan gertatzen bada, aldiz, lehendakaritzaren ardura Errepublikako lehendakariordeari ematen zaio, zeinak, lehenengo kasuan bezala, hauteskundeak hilabeteko epean deitzeko betebeharra baitu.

- Hirugarren unea: falta absolutua lehendakariaren zin egitearen ondotik baina agintaldiaren azken bi urteetan gertatzen bada, lehendakariordeak lehendakaritza ondorio guztiekin eta bere aurrekoaren baldintza berdinetan hartzen du, lehendakaria hautatua izan zen konstituzio-aldia amaitu arte.

Ikus daitekeenez, lehen kasuan baino ezingo litzaioke lehendakaritzaren ardura Juan Guaidóri eman, baina ez da hori gertatu zena. Nicolás Madurok Errepublikako lehendakaritza 2018ko urtarrilaren 10ean zin egin zuen, Juan Guaidó lehendakari urtarrilaren 23an autoizendatu zen bitartean; hots, zin egitea baino 13 egun beranduago. Egun haietan lehendakariaren falta absolutua gertatu izan balitz (eta ez zen gertatu), Errepublikako lehendakaritzaren ardura Delcy Rodríguezi eman beharko zitzaiokeen, berehalakoan gainera, 233. artikuluak jasotzen dituen uneetatik bigarrenean egoteagatik. 2017an deklaratutako karguaren abandonuari lotuko bagina ere, emaitza berbera izango litzateke.

\section{Ba al dago hautatutako lehendakaririk ez egotean 233. artikulua modu analogikoan aplikatzerik?}

Behin 233. artikuluaren hitzez hitzeko interpretazio bat eginez Juan Guaidó Venezuelako lehendakari izendatzeko aukera baztertuta, geure buruari galdetzen diogu: ba al dago honako artikulua modu analogikoan aplikatuz izendapen hori baliozko eran egitea?

Hori da, hain zuzen (eta aurretik esan bezala), Venezuelako oposizioak eta zenbait adituk ${ }^{25}$ defenditu dutena. Horretarako, osoko emendakin bat egin diote errealitatean gertatutakoari. Nola? 2018ko maiatzaren 20an hauteskunderik egon izana ukatzen dute bi gauza baieztatu ahal izateko. Lehena, Maduro lehendakarikargua usurpatzen ari dela (Hernández, 2019b); bigarrena, modu zilegian hautatutako lehendakaririk ez dagoenez, botere-hutsune hori 233. artikulua analogikoki aplikatuz bete behar dela. Fikzio horren emaitza: Juan Guaidó lehendakari.

Posible da aurrekoa egitea? De facto bai, gertaerek hala frogatzen baitute; baina hemen interesatzen zaiguna oposizioak egindakoa juridikoki balioduna den aztertzea da. Horretarako, Zuzenbidearen interpretazio-arauetara jo beharko dugu, zeinek nornahik Zuzenbidea bere nahien edo interesen arabera interpretatzea ekiditen baitute.

25. rewer-Carías, 2019a: 13 eta hur.

«The simplest and most straightforward reading of this provision (art. 233) is that in an analogous situation in which there is no president, the president of the National Assembly "shall take charge of the Presidency of the Republic." Indeed, a situation entirely without an elected president necessitates this action by the National Assembly even more than one in which the president is permanently unavailable but potentially has a cabinet or other government officials in place. In such a situation, the National Assembly is the only properly constituted government branch, popularly elected body and sole representative of the people» (Zambrano, 2019). 
Venezuelako lege-sisteman, espainiar eraentzaren kasuan bezala, Zuzenbidearen interpretazio-arauak Kode Zibilean daude jasota. Zehazki, bere 4. artikuluak honela dio:

Legeari hitzen berezko esanahian agerikoa den zentzua eman behar zaio, bai hitzek haien artean duten loturaren eta legegilearen xedearen arabera. Legearen xedapen zehatzik ez balego, antzeko kasuak edo gai analogoak arautzen dituzten xedapenak hartuko dira aintzat; eta, halere zalantzarik balego, Zuzenbidearen printzipio orokorrak aplikatuko dira.

Ikus daitekeenez, analogia Venezuelako eraentza juridikoan baliagarria den interpretazio-irizpidea da, betiere arauen interpretazio literal eta teleologikotik arazo zehatz batentzako irtenbide juridiko balioduna atera ezin denean. Ez da kasua.

Venezuelan, oposizioak onartu nahi ez badu ere, joan zen 2018ko maiatzaren 20an 9.300.000 herritarrek parte hartu zuten lehendakaritzarako hauteskundeak izan ziren. Madurok, 6.200 .000 bozkatik gora eskuratuta, garaipen garbia lortu zuen, eta ez da horrela guk esaten dugulako; hala da Konstituzioaren arabera horretarako eskumena duen hauteskunde-organo gorena den HKNk horrela baieztatu duelako.

Espainiako Estatuan ez bezala, non boterea formalki hirutan banatzen baita, Venezuelan hauteskunde-boterea botere publiko nazionalaren bost adarretako bat dela ezartzen du Konstituzioak 136. artikuluan, botere betearazlearekin, legegilearekin, judizialarekin eta moralarekin batera. Adar horiek bereizketa- eta kooperazio-printzipioen arabera funtzionatzen dute.

HKN ez da, konstituzionalki behintzat (praktikan ere ez), Maduroren mendeko organoa (292.-298. artikuluak irakurri besterik ez dago). Konstituzioak ezartzen duen moduan, Venezuelako hauteskunde-prozesuak antolatu eta ikuskatzeko eskumena duen organoa da, eta berari baino ez dagokio hauteskundeen deuseztasun total edo partziala ebaztea (293.4 art.). Haren independentzia organikoa eta autonomia funtzionala eta aurrekontu-autonomiak Konstituzioan blindaturik daude (294. art.).

Hori dela-eta, oposizioak ez du egin zuena egiteko oinarri juridikorik. Ezin dute, Konstituzioan oinarrituz, hauteskunde-organo eskudunak balioduntzat jotako emaitza elektorala errefusatu. Nicolás Maduroren autoritatea ukatu nahi badute egin dezakete, jakina, baina ez indarrean dagoen Konstituzioan oinarrituz, de facto baizik, estatu-kolpe baten bidez. Eta hori da, gure aburuz, egiten saiatzen ari direna, errealitate hori estaltzeko berniz juridiko asko ematen badiote ere.

Izan ere, Olga Álvarez konstituzio-abokatuak baieztatzen duen bezala ${ }^{26}$, joan zen maiatzaren 20an hauteskunde-prozesu baliodunik egon izan ez balitz ere, irtenbide konstituzionala oposizioak planteatzen duenetik oso urrun dago. Ezin da 233. artikulua modu analogikoan aplikatu, balizko gertaera horretarako konstituzioirtenbideak aurreikusita daudelako.

Oposizioak esaten duen moduan hauteskunderik egon izan ez balitz, presidentearen amaitutako agintaldian geundeke. Horren aurrean, HKNri hauteskundeak deitzeko eskatu beharko litzaioke lehenbizi, eta aurrekoak hori egin ezean, JAGko

26. 2019ko martxoaren 6an egindako elkarrizketa erdi-egituratua. 
Konstituzio Salari hauteskundeak deitzeko agindua emateko eskatu beharko litzaioke (266., 335. eta 336. artikuluak ${ }^{27}$ ).

Zer gertatuko litzateke bitartean? Bitartean Nicolás Madurok jarraituko luke karguan, amaitutako agintaldian lehendakari izandakoak ezin baitu kargua hauteskunde-prozesu berria egon eta lehendakari berria izendatzen ez den artean utzi. Gainera, edozein arrazoi dela medio Madurok uko egitea erabakiko balu, une horretan Errepublikako lehendakaritza bere gain hartuko lukeena Delcy Rodríguez lehendakariordea litzateke. Legelari garrantzitsu horrek esan bezala, «Venezuelako Konstituzioan ez da posible botere-hutsunea ematerik, halakorik ekiditeko irtenbide konstituzional argiak baitaude ${ }^{28}$ ».

\section{Zer esan du JAGk gertatutako guztiaren inguruan?}

Venezuelako JAGk urte hasieratik epai ezberdinak eman ditu, sortu diren eztabaida juridiko ezberdinei erantzuna emanez.

Haietako lehenbizikoan ${ }^{29}$, auzitegiak herritar batek jarritako interpretaziohelegiteari erantzuna eman zion. Helegite horretan, goi-auzitegiak Konstituzioaren 231. artikuluaren ${ }^{30}$ arabera Maduro lehendakariak kargua zein botere publikoren

27. 266. art.: «Son atribuciones del Tribunal Supremo de Justicia: 1. Ejercer la jurisdicción constitucional conforme al Título VIII de esta Constitución. (...). 4. Dirimir las controversias administrativas que se susciten entre la República, algún Estado, Municipio u otro ente público, cuando la otra parte sea alguna de esas mismas entidades, a menos que se trate de controversias entre Municipios de un mismo Estado, caso en el cual la ley podrá atribuir su conocimiento a otro tribunal. (...) 9. Las demás que establezca la ley. La atribución señalada en el numeral 1 será ejercida por la Sala Constitucional; las señaladas en los numerales 2 y 3, en Sala Plena; y las contenidas en los numerales 4 y 5, en Sala Político administrativa. Las demás atribuciones serán ejercidas por las diversas Salas conforme a lo previsto en esta Constitución y en la ley. Sección Tercera: Del Gobierno y de la Administración del Poder Judicial».

335. art.: «El Tribunal Supremo de Justicia garantizará la supremacía y efectividad de las normas y principios constitucionales; será el máximo y último intérprete de esta Constitución y velará por su uniforme interpretación y aplicación. Las interpretaciones que establezca la Sala Constitucional sobre el contenido o alcance de las normas y principios constitucionales son vinculantes para las otras Salas del Tribunal Supremo de Justicia y demás tribunales de la República».

336. art.: "Son atribuciones de la Sala Constitucional del Tribunal Supremo de Justicia: 1. Declarar la nulidad total o parcial de las leyes nacionales y demás actos con rango de ley de la Asamblea Nacional, que colidan con esta Constitución. (...) 7. Declarar la inconstitucionalidad de las omisiones del poder legislativo municipal, estadal o nacional cuando haya dejado de dictar las normas o medidas indispensables para garantizar el cumplimiento de esta Constitución, o las haya dictado en forma incompleta; y establecer el plazo y, de ser necesario, los lineamientos de su corrección. 8. Resolver las colisiones que existan entre diversas disposiciones legales y declarar cuál debe prevalecer. 9. Dirimir las controversias constitucionales que se susciten entre cualesquiera de los órganos del Poder Público. 10. Revisar las sentencias definitivamente firmes de amparo constitucional y de control de constitucionalidad de leyes o normas jurídicas dictadas por los tribunales de la República, en los términos establecidos por la ley orgánica respectiva. 11. Las demás que establezcan esta Constitución y la ley».

28. 2019ko martxoaren 6an egindako elkarrizketa erdi-egituratua.

29. Venezuelako JAGko Konstituzio Aretoaren 1. epaia, 2019ko urtarrilaren 8koa.

30. 231. art.: «El candidato elegido o candidata elegida tomará posesión del cargo de Presidente o Presidenta de la República el diez de enero del primer año de su período constitucional, mediante juramento ante la Asamblea Nacional. Si por cualquier motivo sobrevenido el Presidente o Presidenta de la República no pudiese tomar posesión ante la Asamblea Nacional, lo hará ante el Tribunal Supremo de Justicia». 
aurrean zin egin behar zuen ebatz zezan eskatzen zen. Alegia, Asanblada Nazionalaren aurrean ala JAGren aurrean egin behar ote zuen.

Auzitegiak ez zuen zalantza askorik izan: Asanblada Nazionalak bere epai ezberdinei men egiten ez zienez, Konstituzioaren 231. artikuluan oinarrituz, ezinezkoa zen lehendakariak Asanbladaren aurrean kargua zin egitea. Ondorioz, JAGren aurrean egitea agindu zuen ${ }^{31}$.

Erabaki hori, gainera, egun bat beranduago emandako beste sententzia batean ${ }^{32}$ berretsi zuen. Bigarren sententzia horrek 231. artikuluari buruzko beste interpretazio-helegite bati eman zion erantzuna, baina erabakia bera baino areago, auzitegiak aintzat hartutako gogoetak dira interesgarrienak, oposizioak 2018ko lehendakaritzarako hauteskundeen baliotasuna auzitan jartzeko erabili zituen funtsezko bi elementuren gainekoak direlako:

1) Hauteskunde-prozesu hartan izandako abstentzio-maila altua, oposizioaren arabera prozesu haren zilegitasuna zalantzan jarriko lukeena.

2) Hauteskunde-deialdia Asanblada Nazional Konstituziogileak egin izana, oposizioaren ustez horretarako eskumenik ez zuenean.

Lehenbiziko alderdiari dagokionez, auzitegiak 1999ko Konstituzioak bozka eskubide bezala soilik arautzen zuela gogorarazi zuen (1961eko Konstituzioak ez bezala, zeinaren arabera bozka eskubidea eta betebeharra baitzen). Horregatik, lehendakaritzarako hauteskundeetan parte-hartzea \% 50etik behera egoteak zilegitasun politikoaren inguruko eztabaida mahaigaineratu balezake ere ${ }^{33}$, terreno juridikoan ez zuen inolaz ere hauteskunde-prozesua baliogabetzen. Zergatik? Bada, Venezuelako zuzenbidean ez dagoelako \% 50eko parte-hartzea gainditzen ez duten hauteskunde-prozesuak baliogabetzen dituen araurik ${ }^{34}$.

31. «En cuanto a la interrogante sobre ante cuál órgano del Poder Público debe juramentarse el ciudadano Nicolás Maduro Moros para el ejercicio del cargo de Presidente de la República para el cual fue electo en los comicios presidenciales el pasado 20 de mayo de 2018, esta Sala reitera, una vez más, que el Órgano Legislativo Nacional se encuentra en flagrante desacato, y por ser este un motivo por el cual el Presidente de la República no puede tomar posesión ante la Asamblea Nacional, tal como lo dispone la norma contenida en el artículo 231 del Texto Fundamental, lo hará ante el Tribunal Supremo de Justicia, para lo cual se convoca al ciudadano Nicolás Maduro Moros para el día 10 de enero de 2019, a las 10 a.m. para que se presente ante el Tribunal Supremo de Justicia a los fines de ser juramentado como Presidente Constitucional de la República Bolivariana de Venezuela para el período presidencial 2019-2025. Así se decide». Venezuelako JAGko Konstituzio Aretoaren 1. epaia, 2019ko urtarrilaren 8koa.

32. Venezuelako JAGko Konstituzio Aretoaren 2. epaia, 2019ko urtarrilaren 9koa.

33. Zilegitasun politikoaz eztabaidatu daiteke, baina datu bat ahaztu gabe: Madurok, oposizioaren abstentzio eta boikoterako deia gaindituz (hauteslekuak eraso ziren eta hautesleak mehatxatu) Trumpek AEBn, Macrik Argentinan edo Piñerak Txilen lortutako herri-bozkaren ehuneko altuagoa eskuratu zuen (zehazki hautesle-erroldaren \% 31,7ko babesa lortu zuen, Trumpen \% 27,3ren, Macriren \% 26,8ren edo Piñeraren \% 26,5en aurrean). Inork jartzen al du auzitan hiru lehendakari horien zilegitasun demokratikoa? Argigarria da honako artikulua: «¿Quién tiene más aval de votos? ¿Trump, Macri, Santos, Piñera... o Maduro?», Cubana y Catracha, 2018/05/27. Ikus: <https://cubanaycatracha.wordpress.com/2018/05/27/ quien-tiene-mas-aval-de-votos-trump-macri-santos-pinera-o-maduro/> (azken kontsulta: 2019/05/13).

34. Hitzez hitz, zera esan zuen: «El ejercicio del derecho al sufragio, es una manifestación de soberanía que no puede ser desconocida por la falta de participación de aquellos que deciden no hacerlo, porque, precisamente, esa decisión de no intervenir o participar es también un derecho y, como tal, no puede menoscabar el derecho al sufragio para la elección de las autoridades cuyos cargos son 
Bigarren alderdiari dagokionez, Aretoak 2017ko maiatzaren 1ean Asanblada Nazional Konstituziogilearen hautaketa eta eratzerako herriaren jatorrizko botere konstituziogilea deitua izan zela gogorarazi zuen (Asanblada 2017ko abuztuaren 4an eratu zen).

Horrekin batera, doktrinan aho batez onartutako zerbait ekarri zuen gogora: jatorrizko botere konstituziogilea komunitate politikoak bere buruaren antolaketa juridiko eta konstituzionala ezartzeko duen jatorrizko eskumena da, ezarritako erregimen juridikoaren aurretikoa dena eta hari gailentzen zaiona, eta Konstituzioak berak ere arautu edo bere agerpenak modu finkoan ezartzerik ez duena. Horrela, bere ezaugarriak direla-eta, estatuz kanpoko «organo ahalguztidun» bezala hauteskundeak deitu zitzakeela ebatzi zuen, are gehiago, "gizartearen ordena eta bakea mantentzen saiatzeko» bazen ${ }^{35}$.

Gauzak horrela, Konstituzio Aretoaren 2019/1 eta 2 epaien arabera, hauteskundeak zilegi izan ziren eta konstituzio-lehendakaria herriak hautatu zuena da: Nicolás Maduro.

Baina auzitegia ez zen hor gelditu. Asanblada Nazionalak herrialdearen instituzionalitate osoari aurka egiten zioten urratsak eman ahala, erabaki berriak hartzen joan zen.

Horrela, urteko hirugarren sententziaren bidez (ofizioz emandakoa, erabat ezohikoa dena) ${ }^{36}$, Asanbladak hartutako hainbat erabaki garrantzitsu baliogabetu zituen. Alde batetik, urtarrilaren 5ean egindako Asanblada Nazionalaren zuzendaritza berriaren izendapena; eta bestetik, urtarrilaren 15ean adostutako lau xedapen, zeinen artean idazki honen hasieran aipatutakoa baitzegoen; hots, Nicolás Maduroren usurpazio-egoera deklaratzen zuena (hurrengo lerroetan azken horren azterketan zentratuko gara).

Bere arrazoibidea 2017ko urtarrilaren 11ko bigarren sententziako epaitza gogora ekarriz hasi zuen Aretoak. Bertan, men ez egitea mantendu bitartean, «hemen erabakitakoaren kontra» zihoan "Asanblada Nazionalaren edozein jokabideren» konstituzioaren kontrakotasuna eta baliogabetasuna ebazten ziren. Horrekin bakarrik, printzipioz, aski litzateke Asanbladaren zuzentarau berria eta urtarrilaren 15eko akordioak bertan behera uzteko, baina, «publikoa, nabarmena eta komunikazionala» zenez Asanbladak 2/2017ko epaitzaren xedapenei men egin gabe jarraitzen zuela, Salak honakoa ebatzi zuen:

- Batetik, Asanblada Nazionalak ez zuela zuzendaritza-batzorde baliodunik eta 2019ko urtarrilaren 5ean hautatutakoak, bere aurretikoek bezala,

de elección popular, a quienes decidan expresar su voluntad mediante el voto libre, secreto, universal y directo. (...) la falta de participación es responsabilidad sólo de quien o quienes dispongan no ejercer su derecho al sufragio activo, por lo que resultaría un contrasentido la pretensión de imponer la abstención como mecanismo de desconocimiento de la voluntad de quienes sí ejercieron su derecho al sufragio».

35. Epaiak oso kritika gogorrak jaso zituen jurista opositoreen partetik, besteak beste, BrewerCaríasena (Brewer-Carías, 2019b).

36. Guztiz ohiz kanpokoa den zerbait da, baina Tribunalaren hitzetan, Konstituzioaren 266.1, 333. 334., 335. eta 336. artikuluen babespean egina. 
autoritatea usurpatu zuela. Ondorioz, Konstituzioaren 138. artikuluaren arabera, bere egintza guztiak «deuseztasun absolutuz nuluak» ziren.

- Bestetik, usurpazio-adierazpenari buruzko akordioak Konstituzioaren 130., 131. eta 132. artikuluak «bortxatzen» zituela eta bereziki «pertsona orok Konstituzioa bete eta obeditzeko duen betebeharra».

Nola arrazoitu zuen auzitegiak?

- Lehenik: Asanblada Nazionala botere guztiak desobeditzen ari zela ezarri zuen (judiziala, betearazlea, elektorala eta, bereziki larria, herriari, subiranotasunaren titularrari egindako desobedientzia).

- Bigarrenik: oposizioak onartutako akordioa Konstituzioa eta botere publikoen egintza guztiak indargabetzeko asmoa zuen indarkeriazko ekintza zela ezarri zuen (hau izan zen, Aretoaren arabera, ofizioz aritu behar izanaren arrazoia).

- Hirugarrenik: aurrekaririk gabekotzat jo zuen oposizioak, Errepublikako lehendakariaren falta absolutua justifikatu ahal izateko Konstituzioaren 233. artikuluan «zehazki» jasota dauden arrazoiak analogiaren bidez zabaldu nahi izatea. Auzitegiaren hitzetan, "ezin zaie aipatutako arrazoiei beste "moldaerraz" bat gehitu nahi den fikzio juridiko baten bidez gure herrialdean 2018ko maiatzaren 20an hauteskunderik izan ez zenik eta [...] estatuburua hautatu ez zenik xedatzeko. Arrazoi horiek zuzenbide zorrotzekoak dira eta ezin dira Konstituzioa bortxatu gabe analogikoki aldatu edota hedatu».

- Laugarrenik: 2003ko urtarrilaren 22ko 24. epaiari aipamena eginez (dagoeneko honako testuan aipatua izan dena), eratutako organo batek Konstituzioari egindako berariazko bortxaketak justifikatu nahirik 350 . artikuluari aipu egitea «erabat desegokia» dela gogorarazi zuen.

- Bosgarrenik: «Asanblada Nazionalak usurpazioa ebatzi ahal izateko JAGren mailara ezin dela igo» argitu zuen, «aurretik aipatutako Konstituzioaren 138. eta 139. artikuluek 136. eta 137. artikuluekin bat etorrita deskribatzen duten jokabidearen tipifikazioa ekarriko bailuke ${ }^{37}$ ».

- Azkenik, begi-bistakoa den zerbait gogorarazi zuen; Venezuela erregimen «nagusiki presidentziala» dela. Horregatik, hain zuen, Parlamentuak ezin zituen inolaz ere Gobernuaren edo Ogasun Publikoaren administrazioaren egitekoak bere egin, lehendakariari baitagozkio aipatutako funtzioak (236.2, 11., 12. eta 14. artikuluen arabera, besteak beste).

37. 136 art.: «El Poder Público se distribuye entre el Poder Municipal, el Poder Estadal y el Poder Nacional. El Poder Público Nacional se divide en Legislativo, Ejecutivo, Judicial, Ciudadano y Electoral. Cada una de las ramas del Poder Público tiene sus funciones propias, pero los órganos a los que incumbe su ejercicio colaborarán entre sí en la realización de los fines del Estado».

137. art.: «Esta Constitución y la ley definen las atribuciones de los órganos que ejercen el Poder Público, a las cuales deben sujetarse las actividades que realicen».

138. art.: «Toda autoridad usurpada es ineficaz y sus actos son nulos».

139. art.: «El ejercicio del Poder Público acarrea responsabilidad individual por abuso o desviación de poder o por violación de esta Constitución o de la ley». 
Finean, 2018ko lehendakaritzarako hauteskundeen emaitza aitortu gabe Maduro usurpatzaile izendatzen zuen Asanblada Nazionalaren akordioa zuzenbide osoz deuseza deklaratu zuen. Horregatik, gaur-gaurkoz konstituzio-zilegitasuna duen lehendakari bakarra Nicolás Maduro da. Horrela berretsi izan du, gainera, ondorengo epaietan ere ${ }^{38}$.

\section{Ondorioak}

Aztertutako guztiaz honako ondorioak atera daitezke:

1) Joan zen 2018ko maiatzaren 20 an lehendakaritzarako hauteskundeak izan ziren Venezuelan. Aipatu hauteskundeak Konstituzioarekin bat etorrita egin ziren: garbiak, gardenak eta lehiakorrak izan ziren (oposizioko hautagai ezberdinen parte-hartze askearekin). Horrela aitortu zuten behintzat, horretarako eskudun ziren hauteskunde-organo eta auzitegiez gain, bertaratutako nazioarteko ikuskariek.

2) Nicolás Maduro, 6.200 .000 bozekin, hauteskunde haietan garaile atera zen. Parte-hartzea, oposizioaren parte batek sustatutako boikotaren eraginez, zinez baxua izan zen (\% 43 ingurukoa), baina horrek ez ditu hauteskundeak juridikoki baliogabetzen. Auzitegiek irmoki baieztatu bezala, Venezuelan bozka eskubidea da, ez betebeharra. Ez dago parte-hartzea \% 50era iristen ez denean hauteskunde-prozesua baliogabetzea ahalbidetzen duen araurik (Espainiako Estatuan ere ez dagoen bezala, non antzeko partehartzea izan duten hauteskunde-prozesuak -EBren Konstituzioari buruzko erreferenduma kasu — zilegi eta balioduntzat jo diren).

3) Hauteskunde-deialdi hura Asanblada Nazional Konstituziogileak deitu izanak ere ez du prozesua baliogabetzen. Jatorrizko boterea denez, ezarritako ordenamendu juridikoari gailentzen zaio eta horretarako eskumena du, auzitegiek berretsi dutenez.

4) Ondorioz, ez dago oposizioak zalapartaka aldarrikatzen duen boterehutsunerik edota lehendakari-karguaren usurpaziorik. Alde batetik, baieztatu berri den bezala, auzitegiek berek hala ebatzi dutelako; baina bestetik, eta funtsean, Venezuelako herriak hala ezarri zuelako, 2018ko maiatzaren 20an 9.300.000 hautesle baino gehiago bozkatzera joatean.

5) Konstituzioaren 233. artikulua ezin zaio aztertzen ari garen kasuari aplikatu. Ez da artikuluak aurreikusten dituen lehendakariaren faltarako sei arrazoietatik bat bera ere eman, eta beraz, ezin da artikulu horretan oinarrituz lehendakari arduradunik izendatu.

6) Aipatu artikuluaren aplikazio analogikorik ere ezin da egin. Boterehutsunerik ez dagoela argi eta garbi esan dugu aurretik, baina egongo balitz ere (2018ko hauteskundeak baliozkoak izan ez zirelako), Konstituzioaren

38. Adibidez, 2019ko 4. eta 5. epaiak aipa litezke. Lehenak Asanblada Nazionalak hartutako hiru erabaki indargabetu egiten ditu (OEAra atxikitzea, OEAren aurreko ordezkari berezia izendatzea eta urtarrilaren 23ko ospakizuna herriak demokrazia berreskuratu zuen egun bezala). Bigarrenak Nicolás Maduro lehendakariak aldarrikatutako salbuespen-egoerari konstituzio-babesa ematen dio. 
arabera Nicolás Madurok jarraitu beharko luke bere karguan, deialdi berria egin arte. Venezuelako Konstituzioan ez dago boterearen hutsunerako tarterik, hori ekiditeko irtenbide konstituzional garbiak daude eta.

7) Maduro 233. artikuluan aurreikusitako falta absoluturako arrazoietako batean jausi eta lehendakari arduradun izendatu behar izan balitz ere, halako ohorea egungo lehendakariordea den Delcy Rodríguezi egokituko litzaioke. Juan Guaidó Maduroren falta bere zin-egite ekitaldia ospatu aurretik (hots, urtarrilaren 10a aurretik) gertatu izan balitz baino ezin izango litzateke lehendakari arduradun izan, eta publikoa den bezala, urtarrilaren 23an autoizendatu zen lehendakari.

8) Aurreko guztiagatik, Juan Guaidók Errepublikako lehendakari arduradun bezala egindako autoizendapena guztiz konstituzio-kontrakoa da. Konstituziozilegitasuna eta zilegitasun demokratikoa dituen lehendakari bakarra Nicolás Maduro Moros da.

9) Oposizioak Maduroren autoritatea ez aitortzeko eta ez obeditzeko aukera du, baina de facto baino ez dezake jokatu, ez baitu egiten ari dena egiteko konstituzio-oinarririk. Horixe bera da, gure ustez, egiten ari dena: estatukolpea saiatu eta atzerriko esku-hartze militarra sustatu. Asko saiatuta ere, nekez ematen ahal zaio horrelako mugimendu bati estaldura konstituzionalik. Ez hemen, ez Venezuelan, ez inon.

\section{Bibliografia}

Asamblea Nacional de Venezuela (2017): «Acuerdo sobre el abandono de las funciones constitucionales de la Presidencia de la República en que ha incurrido Nicolás Maduro Moros», Gaceta Legislativa, 2017ko urtarrilaren 9a. Ikus: <http:// www.asambleanacional.gob.ve/actos/_acuerdo-sobre-el-abandono-de-lasfunciones-constitucionales-de-la-presidencia-de-la-republica> (azken kontsulta: 2019/05/13).

(2019a): «Acuerdo sobre la declaratoria de usurpación de la Presidencia de la República por parte de Nicolás Maduro Moros y el restablecimiento de la vigencia de la Constitución», Gaceta Legislativa, 2019ko urtarrilaren 23a. Ikus: <http://comisiones.an.gob.ve:8080/admin/views/archivos/Gaceta\%20Legislativa_ digital\%20(3).pdf> (azken kontsulta: 2019/05/13).

(2019b): «Estatuto que rige la transición a la democracia para restablecer la vigencia de la Constitución de la República Bolivariana de Venezuela», Gaceta Legislativa, 2019ko martxoaren 14a.

Biagini, H.E. (1978): «El ius resistendi de Locke», Revista de Estudios Políticos, 2.

Bonilla-Molina, L. eta El Troudi, H. (2005): Historia de la Revolución Bolivariana, Pequeña crónica 1948-2004, Universidad Bolivariana de Venezuela, Caracas.

Brewer-Carías, A.R. (2018): «Las faltas absolutas del Presidente de la República en el Derecho Constitucional venezolano", in D. García Belaunde eta J. Tupayachi Sotomayor (koord.), La vacancia por incapacidad moral. Una mirada a la experiencia peruana y comparada, 2. edizioa, Instituto Pacífico, Lima.

, (2019a): «El Régimen en su laberinto y la Asamblea Nacional al rescate de la democracia", academia.edu, 2019ko urtarrila. Ikus: <https://www.academia. edu/38272524/188._Brewer._El_r\%C3\%A9gimen_en_su_laberinto_y_la_AN_al_ rescate_de_la_democracia_enero_2019.pdf> (azken kontsulta: 2019/05/13). 
(2019b): «El Juez Constitucional en Venezuela y la juramentación de Nicolás Maduro como Presidente de la República ante el Tribunal Supremo de Justicia el 10 de enero de 2019», allanbrewercarias.com, 2019ko urtarrila. Ikus: <https:// allanbrewercarias.com/wp-content/uploads/2019/01/187.-El-Juez-Constitucionaly-el-juramento-de-N.-Maduro-el-10-1-2019.-1.pdf> (azken kontsulta: 2019/05/13).

Compains Silva, E. (2016): Botere konstituziogilea latinoamerikar konstituzionalismo berrian, IVAP, Basauri (Bizkaia).

Hernández, J.I. (2019a): «¿Y qué dice el artículo 233 de la Constitución?», Prodavinci.com, 2019ko urtarrilaren 11. Ikus: <https://prodavinci.com/y-que-dice-el-articulo-233de-la-constitucion/> (azken kontsulta: 2019/05/13).

(2019b): «La usurpación de la Presidencia de la República a partir del 10 de enero de 2019: consecuencias en el derecho constitucional y en el derecho internacional», Academia.edu, 2019ko urtarrilaren 9a. Ikus: <https://harvard. academia.edu/Jos\%C3\%A9IgnacioHern\%C3\%A1ndezGonz\%C3\%A1lez> (azken kontsulta: 2019/05/13).

Pérez Royo, J. (2005): «La interpretación de la Constitución», in E. Ferrer McGregor (koord.), Interpretación constitucional, UNAM, Ed. Porrúa, Mexiko.

Sader, E. (2019): «Venezuela tiene un solo Presidente», Diario Público, 2019ko otsailaren 27 an.

Zambrano, D. (2019): «Guaidó, not Maduro, is dejure President of Venezuela», Stanford Law School Blogs, 2019ko otsailaren 1a. Ikus: <https://law.stanford.edu/2019/02/01/ guaido-not-maduro-is-the-de-jure-president-of-venezuela/> (azken kontsulta: 2019/05/13).

\section{Jurisprudentzia}

- Venezuelako JAGko Konstituzio Aretoaren 24. epaia, 2003ko urtarrilaren 22koa.

- Venezuelako JAGko Konstituzio Aretoaren 2. epaia, 2017ko urtarrilaren 11koa.

- Venezuelako JAGko Konstituzio Aretoaren 7. epaia, 2017ko urtarrilaren 27koa.

- Venezuelako JAGko Konstituzio Aretoaren 1. epaia, 2019ko urtarrilaren 8koa.

- Venezuelako JAGko Konstituzio Aretoaren 2. epaia, 2019ko urtarrilaren 9koa.

- Venezuelako JAGko Konstituzio Aretoaren 3. epaia, 2019ko urtarrilaren 21ekoa.

- Venezuelako JAGko Konstituzio Aretoaren 4. epaia, 2019ko urtarrilaren 23koa.

- Venezuelako JAGko Konstituzio Aretoaren 5. epaia, 2019ko urtarrilaren 25ekoa.

- Venezuelako JAGko Konstituzio Aretoaren 6. epaia, 2019ko otsailaren 9koa.

\section{Berriak}

«Última hora! Juan Guaidó se proclama Presidente encargado de Venezuela», Youtube, 2019/01/23 (azken kontsulta: 2019/05/13). Ikus: <https://www.youtube.com/ watch?v=1xSRWhlk|xo>.

«Naciones Unidas reconoce a Maduro como Presidente de Venezuela», Radio Rebelde, 2019ko otsailaren 1a (azken kontsulta: 2019/05/13). Ikus: <http://www. radiorebelde.cu/comentarios/naciones-unidas-reconoce-maduro-comopresidente-venezuela-20190201/>. 
«Jimmy Carter: el sistema electoral venezolano es el mejor del mundo», Russia Today, 2012ko irailaren 20a (azken kontsulta: 2019/05/13). Ikus: <https://actualidad. rt.com/actualidad/view/54145-jimmy-carter-sistema-electoral-venezolano-mejormundo>.

«Los observadores internacionales avalan la reelección de Maduro», eitb.eus, 2018ko maiatzaren 22a. Ikus: <https://www.eitb.eus/es/noticias/internacional/ detalle/5608975/venezuela-elecciones-los-observadores-avalan-reeleccionmaduro/>.

«¿Quién tiene más aval de votos? ¿Trump, Macri, Santos, Piñera... O Maduro?», Cubana y Catracha, 2018/05/27 (azken kontsulta: 2019/05/13). Ikus: <https:// cubanaycatracha.wordpress.com/2018/05/27/quien-tiene-mas-aval-de-votostrump-macri-santos-pinera-o-maduro/>. 
